\title{
Entregue ao Prof. Emérito Waldemar Ferreira o Prêmio "Moinho Santista de 1958"
}

Em sessão solene realizada no dia 30 de setembro de 1958, no salão nobre da Faculdade de Direito da Universidade de S. Paulo, procedeu-se à entrega do "Prêmio Moinho Santista de 1958 Para Ciências Especulativas" ao eminente jurista patrício Waldemar Martins Ferreira. Achavam-se presentes, entre outras pessoas gradas, os srs. Francisco Cunha Ribeiro, representante do presidente da República; Francisco de Paula Vicente de Azevedo, secretário da Fazenda; João Marcellino Gonzaga, presidente do Tribunal de Justiça do Estado; Francisco João Humberto Maffei, vice-reitor da Universidade de São Paulo; padre Artur Alonso, reitor da Universidade Católica do Rio de Janeiro; professor Honório Monteiro, do Conselho Administrativo da Fundação Moinho Santista; Jorge Americano e Manoel Chambers, da direção da Fundação; Dalmo Belfort de Mattos, representante da Universidade Catolica de Campinas, e representantes do clero, dos comandos militares aquartelados nesta Capital e de diversas instituições culturais.

Estiveram também presentes, incorporados, os membros do Conselho da Ordem dos Advogados de São Paulo.

Após a execução do Hino Nacional e aberta a sessãc pelo desembargador João Marcellino Gonzaga, uma comissão de professôres introduziu no recinto o ilustre mestre de Direito, que foi recebido com uma salva de palmas pela numerosa assistência que lotava, literalmente, o salão nobre da Faculdade. 


\section{Saudação}

Em nome do Conselho Administrativo da Fundacão Moinho Santista o professor Honório Monteiro pronunciou o seguinte discurso, saudando o professor Waldemar Ferreira :

"Já tive oportunidade de dizer, não faz mal que repita: tenho minha vida tôda de ex-aluno e de estudioso do Direito, vinculada, por acontecimentos varios, à do egrégio mestre Waldemar Ferreira. Extremamente grato, por isso, ao meu espírito e profundamente sensível ao meu coração, falar nesta solenidade, em que se presta consagração nacional à sua vida de labor fecundo e, ao mesmo tempo, se põe em realce julgamento perfeito e se assinala iniciativa incomum nos meios econômico-financeiros do País.

A iniciativa que se quer assinalar é da Sociedade Anônima Moinho Santista. Seus diretores, embora sujeitos, como sói acontecer, aos entrechoques constantes de interêsses materiais, que quase sempre desgastam e materializam os dirigentes das empresas privadas produtoras de riqueza, continuam sensíveis às coisas do espirito, como demonstraram ao tomarem a iniciativa de propor aos acionistas, que logo aplaudiram, a instituição de um prêmio permanente, incentivo e recompensa, aos que, nos vastos domínios dos conhecimentos humanos, devessem, no Brasil, ser apontados e consagrados periodicamente como expoentes máximos. Dessa iniciativa surgiu a Fundação Moinho Santista, que com apenas três anos de existência, distribui hoje, pela terceira vez, o Prêmio Moinho Santista, consistente em um milhão de cruzeiros em dinheiro, uma medalha de ouro e um pergaminho.

Divididas as disciplinas do conhecimento humano, em quatro setores, tocou o prêmio, no primeiro ano, no setor da Biologia, ao entomologista de renome universal - professor Costa Lima; no segundo ano, no setor das chamadas 


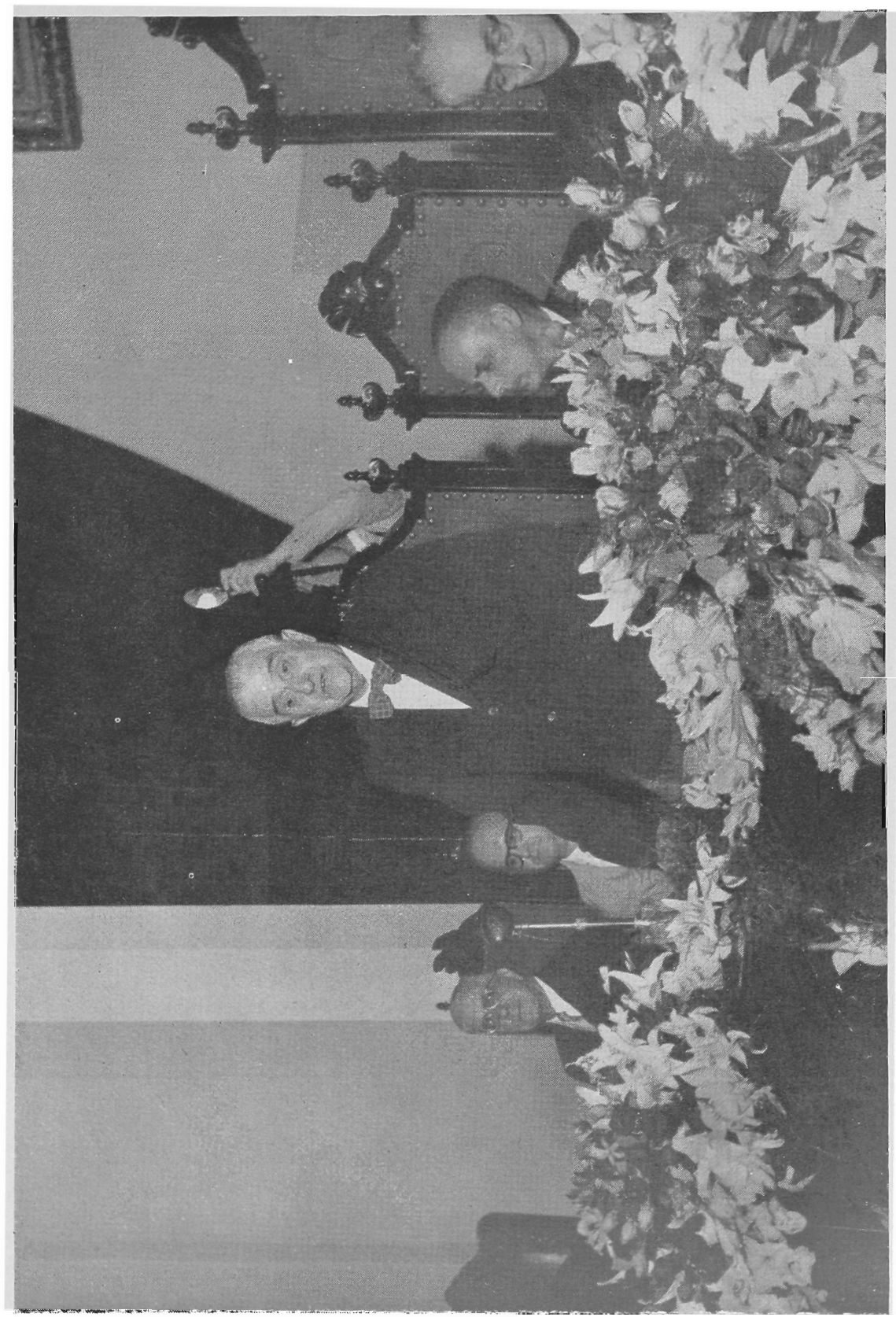

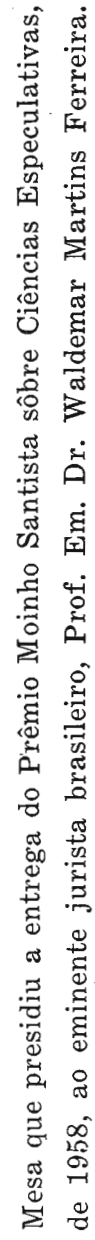


ciências exatas, ao jovem físico Jaime Tiomno, professor da Universidade do Brasil, sendo que êste ano acaba de ser indicado para recebê-lo, como tributo pelos seus inestimáveis serviços prestados ás ciencias juridicas, o prof. emérito Waldemar Ferreira, da Universidade de São Paulo. A seleção dos nomes é feita, de acôrdo com os estatutos da Fundação, por comissões de especialistas nas respectivas disciplinas, livremente designados pelos reitores magníficos das Universidades Brasileiras, oficiais e particulares, comissões estas que, depois de minucioso balanço e confronto dos méritos dos nomes, selecionados em sucessivas reuniões sigilosas, indicam, ao Grande Juri, em envelopes lacrados e que só serão abertos no momento do julgamento, um nome de cada uma das disciplinas componentes do setor. Ėste ano o prêmio se destinava a jurista, ou filosofo ou educador. O Grande Juri é constituído das mais eminentes personalidades do meio cultural do País, como sejam o presidente do Supremo Tribunal Federal, o presidente do Tribunal de Justiça de São Paulo, que nos dá a honra de presidir esta sessão, o presidente da Academia Brasileira de Letras, o presidente da Academia Paulista de Letras, o presidente da Associação Brasileira de Imprensa, o chefe do E. M. F. A., os reitores magníficos das Universidades, além de outros, todos êles, como membros natos, porque designados pelos Estatutos da Fundação Moinho Santista e ainda de mais cinco membros, com conhecimentos especializados nas disciplinas em causa, êstes eleitos pelo Conselho de Administração da Fundação, que tem como presidente o prof. Jorge Americano.

O Grande Juri assim formado de tão conspícuas expressões da cultura, em julgamento secreto, proclamou competir o prêmio Moinho Santista, no corrente ano, ao professor emérito Waldemar Ferreira "por ter êle realizado, com maior mérito, obra de excepcional projeção nacional e internacional e de inquestionável valor para o progresso das ciências especulativas, grangeando a consideração e o reconhecimento público, por seus relevantes 
serviços prestados ás ciências jurídicas", como textualmente se lê no pergaminho que lhe vai ser entregue.

Julgamento perfeito, meus senhores, Waldemar Ferreira representa, em verdade, expressão máxima nacional, do labor ao serviço das ciências jurídicas. No campo do Direito Comercial, que é a sua especialidade e que palmilhou por largos anos, como mestre respeitado e consagrado, ninguém o excedeu entre os juristas que versaram êsse ramo do direito em língua portuguêsa e, talvez, nenhum outro jurista vivo, em país algum, tenha o mérito de personificar uma fase do desenvolvimento do direito comercial no seu País. Sucedendo a Carvalho de Mendonça — de outra feita já o afirmamos perante a Congregação da Faculdade de Direito - não the desmereceu a grande obra, antes completou, com seguro cunho próprio, a sistematização de nosso direito comercial. Escrevendo em periodo tumultuário e de profundas e permanentes perturbações econômicas e de comoções sociais, contrastantes com a serena calmaria da época em que Carvalho de Mendonça construiu o seu tratado, avulta a ação disciplinadora do mestre Waldemar Ferreira, ao plasmar os novos institutos e ao adaptar os existentes às contingências das condições econômicas, políticas e sociais contemporâneas, que pressionam a atividade mercantil e que repercutem na sua disciplinação, sem se deixar perder, porém, no emaranhado e no exagero de doutrinas exóticas, incompativeis com a tradição de nosso direito e a sistemática de nossa legislação.

$\mathrm{E}$ como se não bastasse êsse primado no campo do direito mercantil, para fixar a sua personalidade de jurista, Waldemar Ferreira percorreu ainda os demais ramos do direito, especialmente aquêles mais sensíveis às mutações sociais. Jurista, com raízes profundas na nossa formação histórica, teve oportunidade de marcar sua passagem pelo parlamento nacional com projetos de leis que bem revelam a sua sensibilidade em captar os fatos sociais e discipli- 
ná-los segundo a índole de nossa gente e os princípios informadores de nossas instituições jurídicas.

Sirvam de exemplos os seus projetos sobre o Casamento religioso de efeitos civis e o Loteamento $e$ venda de terrenos a prestações. Coroando a sua inestimável contribuição para o progresso das ciências jurídicas no Brasil, ofereceu-nos mais o Egrégio Mestre quatro volumes sobre a História do Direito Brasileiro, que êle exumou, com labor insano, dos documentos existentes nos arquivos nacionais e estrangeiros e que com admirável sentimento de brasilidade sistematizou; a sua História do Direito Constitucional Brasileiro e, por último, o Direito Público Colonial do Estado do Brasil sob o Signo Pombalino, que está a sair a lume.

Julgamento perfeito, repito. Ninguém melhor que Waldemar Ferreira fêz jus, pela sua ininterrupta atividade jurídica construtora, pelo sentimento nacional que guardou sempre nas suas produções jurídicas, pelo enraigado amor à pátria que lhe serve de berço e que, pelo seu labor profícuo, tanto tem sabido honrar e dignificar, dentro e fora de suas fronteiras; ninguém melhor que Waldemar Ferreira fêz jus ao Prêmio Moinho Santista. Aplausos sem restrições merecem as comissões selecionadoras e, em particular, o Grande Juri, pelo seu julgamento.

Professor Waldemar Ferreira.

Várias homenagens já vos foram prestadas, em testemunho de alto aprêço em que temos, todos nós, o vosso labor fecundo. A Faculdade de Direito conferiu-vos, em solene sessão, a mais conspícua e dignificante das honras de que dispõe, a de Professor Emérito; a Ordem dos Advogados, juntamente com o Instituto dos Advogados de São Paulo e a Associação dos Antigos Alunos desta Faculdade, de que sois filho dileto, prestaram-vos pública homenagem pelas vossas altas qualidades de professor e jurista, de cidadão e de advogado; o Instituto dos Advogados do Brasil, também em sessão solene, conferiu-vos a medalha de bronze "Teixeira de Freitas", em reconhecimento dos ser- 
viços prestados à cultura jurídica do País. São, em verdade, emérito professor, manifestações que sobremodo dignificam uma vida, pelo seu alto significado cultural, e que corroboram o julgamento do Grande Juri da Fundação Moinho Santista.

Contudo, nenhuma delas, cada qual mais valiosa, tem o sentido nacional de que se reveste a que ora vos é prestada. Foram eminentes professôres de direito do Norte, do Sul e do Centro do País que indicaram o vosso nome, como expressão máxima, na atualidade, da cultura jurídica brasileira; foram os representantes das Faculdades de Direito do Recife e da Bahia, das Faculdades de Direito do Rio Grande do Sul e do Paraná; das Faculdades de Direito de Minas Gerais e da Capital Federal e das três Faculdades desta Capital de São Paulo, que aclamaram e o Grande Juri acolheu com aplausos, o Egrégio Mestre como digno de maior consideração e do reconhecimento público pelos relevantes serviços prestados à cultura juridica do Brasil.

O destino, professor Waldemar Ferreira, reservou-vos, após longa e profícua caminhada, as homenagens que vos vêm sendo prestadas e que culminam nesta consagração. E' com profunda emoção, mestre querido, que o vosso mais antigo e por certo mais velho ex-aluno, em nome do Conselho de Administração da Fundação Moinho Santista, vos saúda, juntando os seus aplausos ao calor dos amigos todos que aqui vieram para ainda uma vez vos consagrar.

\section{Discurso do professor Waldemar Ferreira}

Agradecendo a concessão do prêmio Moinho Santista, o professor Waldemar Ferreira pronunciou a seguinte oração:

"Quiçá porque minha circulação sanguínea um tantinho tarda não me propicia ruidosas exaltações emotivas, antes as traduz em expressões de singeleza, eu me hei deliciado mais com os panoramas dos pôres de sol que com os dos 
amanheceres. Se o esplendor dêstes tem ensejado partituras musicais, de majestosa beleza sinfônica, na orquestração de hinos ao sol, a melancolia daqueles tem proporcionado aos poetas sonatas ao crepúsculo, quando expira a surdina das aves e depois, "na sombra, à voz das cornamusas graves, termina a pastoral em lento epitalâmio e a terra desmaia entre o pudor da tarde e a tentação da treva", como no verso bilaqueano.

Jamais me tomou a melancolia a justificar a minha inclinação emotiva diante dos episódios de uma jornada do sol em de redor da terra; mas quis o meu destino de homem feliz que eu viesse a encontrar mais fortes emoções espirituais nos dias da anciania do que nos da infância ou da juventude. Não me proponho neste instante evocar os feitos desta ou daquela, para não ser castigado pela temeridade de recordações tão longínquas. Recordar é viver, diz-se, e é provável que o seja. Não será demasia, no entanto, asseverar que o viver antes está no envelhecer que no recordar. A recordação é a fonte de rejuvenescimento dos que se comprazem em estacar no tempo, como se êste não tivesse o fadário de transformar-se de minuto em minuto e a virtude de conservar-se sempre o mesmo.

Não há todavia quem dela não se sirva, em certos momentos de êxtase espiritual, para o gôzo do agridoce prazer que ela ministra, por via da saudade. E o viver antes reside, e sem sombra de dúvida, no existir, somando os anos. Porque existo, e logo vivo, não foram, nem são poucas as emoções que o pôr de sol da minha vida me há prodigalizado. Não me julgo ainda no ponto de escrever a sonata do crepúsculo, sobretudo em momento como êste, em que, para gaudio meu, recebo consagração impar, que esmaltará minha reputação, que porfiei por engrandecer.

Aprendi em página de antigo mestre da língua que, sendo o homem nascido para sociedade, se, contentando-se com testemunho de sua consciência, desprezar o comum, será injusto consigo, privando-se da honra devida ao vir- 
tuoso; com o próximo, negando-lhe o bom exemplo; e com a virtude, tirando-lhe o meio de se comunicar. Por isto, o homem não é senhor absoluto, mas dispenseiro fiel de sua reputação; pois se a quiser estragar, pelo que lhe toca, a deve conservar pelo que pertence ao público e à mesma virtude, que da fama recebe mais lustre, posto que não receba mais perfeição; e quando seja senhor, as leis proibem usar mal dos bens próprios.

Servo da lei, algumas vêzes elaborador de leis e em todos os meus dias defensor e aplicador da lei, esforcei-me por não usar mal do meu maior bem próprio, para que pudesse dá-lo como exemplo, como pai, a meus filhos, e como professor universitário, a trinta gerações de moços aos quais transmiti o meu ensinamento jurídico. Ora, nenhum de quantos alimentem a expectativa de ganhos morais, capazes de engrandecê-los diante de si mesmos e no meio social em que prosperam, deixa de, em seus solilóquios íntimos e no cômputo de suas possibilidades, ao menos, antever os que caibam ao alcance de sua ambição, afim de os conquistar. Nada mais natural. Nem mais justo.

Se, para aumento de minha reputação, eu dissesse que, num dos meus devaneios, uma vez me passou pela cabeça que me pudesse vir às mãos o prêmio com que sou agora agraciado, ninguém acreditaria. Nem eu mesmo. $\mathrm{E}$ isso pela razão primacial de ser êste prêmio indisputável por quem se considere em condições de o merecer. A ninguém é dado desejá-lo. Cai êle do alto, como a benção do céu, conferido pelo consenso unânime, quando não majoritário, de homens virtuosos e dignos, que funcionam como juízes e até, como no caso presente, revestidos alguns das togas de magistrados. Está nisso sua grandeza, maior ainda pela magnificência desta assembléia, à qual eu rendo o meu reconhecimento, e que o homologa. Eis porque o bendigo. Bendigo-o, mas proclamo que não o recebo como benemerência, embora beneméritos sejam os que o conceberam e o converteram em realidade. 
Conceberam-no diretores duma sociedade anônima industrial; e o realizaram sob a forma fundacional, de modo a instilar-lhe a perpetuidade, sem embargo da transitoriedade das coisas humanas. "Por maior" - disseram êles — "que seja a relevância que se possa atribuir à produção da riqueza material de um país, através da ação das suas fôrças econômicas, o que deveras eleva o conceito de uma nação no mundo e perante ela mesma, é aquêle quinhão com o qual seus filhos contribuem para o acervo de perpétuos valores da humanidade, dignificando-a e melhorando suas condições de vida. São a fagulha do gênio, a inspiração do espírito, a intuição de alma tanto quanto a perserverança metódica de vontades inquebrantáveis que destinam homens singulares à realização de feitos extraordinários. São êstes que, em intermináveis sequências, edificaram, pedra por pedra, culturas e civilizações. No seu pensamento, seu exemplo e suas obras residem as vigorosas fontes das idéias, da moral, da fé, que frutificam e impulsionam a ação humana na sua incansável luta por um ideal de um maior bem-estar".

Por isso, a empresa, que êles superiormente orientam, dirigem e engrandecem, "durante meio século indissolùvelmente ligada à histórica etapa da industrialização da economia brasileira, reconhecendo também a necessidade de uma solidariedade entre a produção econômica e a criação intelectual que proporcione à coletividade e ao País seguro roteiro de progresso", se convenceu da inexistência de "melhor meio de comemorar o cinqüentenário de sua fundação do que instituir um prêmio que possa estimular, permanente e eficazmente, todos quantos, tendo em vista o aperfeiçoamento da pessoa e da cultura humanas, enobrecem por seus serviços da mais vasta projeção o nome do Brasil, tanto nas ciências, como nas artes e na literatura, tributando-lhes, simultâneamente, o reconhecimento ao qual farão jus".

Eis a origem, o sentido e o objetivo do "Prêmio Moinho Santista", com que acabo de ser contemplado; e dêle me 
envaideço. Essa vaidade dimana da nobreza que inspirou a instituição da mercê insigne, provinda de uma empresa industrial que, tendo iniciado sua atividade nesta terra generosa e fecunda há mais de meio século com êxito surpreendente, bem compreendeu que de outra forma além de seu escopo primacial, poderia contribuir para o engrandecimento do País. Nada significaria tal procedimento pelo materialismo da soma monetária, se não tivesse sido superado pelo sentido de dignidade de que se revestiu, de molde a poder ser recebido com sobranceria por homens da valia científica e da estatura moral dos dois cientistas de primeiro galardoados com êste mesmo prêmio com que sou consagrado.

Aquêle, disse São Paulo na segunda epístola aos Coríntios, que subministra semente ao semeador, dará também pão para comer, aumentando a sementeira e multiplicando os frutos da justiça a fim de que, enriquecendo em tôdas as coisas, possa ter abundantemente com que fazer tôda a sorte de liberalidades, que provoquem a graça de Deus. Ajustou-se a êsse versículo do apóstolo o pensamento dos instituidores da fundação, dando-lhe por objetivo não apenas adjudicar anualmente a brasileiro ou a pessoa radicada há mais de cinco anos no País e mais se haja destacado à consideração e reconhecimento públicos, mercê de relevantes serviços no campo das ciências, arte e literatura; como ainda, a favor dos mesmos ideais que inspiraram a instituição daquele prêmio, e desde que os seus recursos isso permitam, dedicar-se ao exercício de atividades assistenciais. Não é insignificante o que neste terreno vêm praticando empresas industriais.

Se, movidas por natural espírito mercantilista, se alargam no espaço, pluripartindo-se em sucursais, filiais e agências, avolumadoras das cifras de seus negócios; se, confederando-se em trustes, fundiram o poderio econômico que lhes deu poderio político internacional; se, ajustandose em cartéis do mais variado estilo, dominaram os mercados, regulando a produção e o consumo, de molde a 
assegurar a obtenção de pingues dividendos - tudo isso não obstou a que elas se humanizassem, de modo a consagrar aos seus operários os mesmos, senão maiores cuidados que os dispensados a suas máquinas e maquinismos,

Embeberam-se do suave humanismo cristão que levou Leão XIII a doutrinar que o que faz próspera uma nação são os costumes puros, as famílias fundadas sobre a base da ordem e da moralidade, a prática da religião, o respeito da justiça, uma tributação moderada e uma repartição equitativa dos cargos públicos, o progresso da indústria e do comércio, agricultura florescente e outros elementos do mesmo gênero, de molde a desenvolver sem aumentar excessivamente o bem estar e a felicidade dos cidadãos.

Adotaram o ensinamento antes mesmo que o Estado, como aconselhou aquêle sumo pontífice, se servisse daquêles meios a fim de se tornar útil a tôdas as classes e, ao mesmo tempo, melhorar grandemente a sorte da classe trabalhadora, usando de todo o rigor de seu direito e sem temer o reproche de ilegitimidade de sua ingerência, por lhe competir a salvaguarda do interêsse comum. Com essa integração da indústria e do comércio no papel de colaboradores da ordem social, vieram as empresas industriais a exercitar função insigne, como autênticos órgãos de colaboração com o Estado, que dela já não mais pode prescindir para sua defesa na ordem interna e principalmente na externa.

Nesta, então, depois da última guerra, a presença das grandes empresas se tornou indispensável, desde que a guerra antes requer mais a técnica dos cientistas do que a tática dos cabos militares, em boa parte ineficiente diante da pujança destrutiva dos inventos industriais.

Nem é possível a prosperidade dessas empresas em nações econômicamente pobres, mais empobrecidas ainda por uma população enfraquecida pelos males sociais e morais. Cabe-lhes quinhão imenso no esfôrço de engrandecimento dos países em que operam; e não podem ser indiferentes, ao mesmo passo, ao seu desenvolvimento ci- 
entífico, cultural e artístico. Ao cumprimento dêsse dever cívico, e por que não o dizer patriótico?, não fugiram os dirigentes da empresa que instituiu, com a fundação de seu nome, o "Prêmio Moinho Santista". No ofício que me

dirigiram os presidentes do Grande Juri e do Conselho Administrativo da Fundação, disseram-me que aquêle prêmio me era concedido por haver eu realizado, "com maior mérito", obra de excepcional projeção nacional e internacional e de inquestionável valor para o progresso das ciências especulativas, obtendo a consideração e o reconhecimento públicos por serviços relevantes prestados às ciências juridicas".

Se não fôsse assim, bem poderia eu asseverar que as palavras com que me enalteceu o professor Honório Monteiro, meu antigo discípulo e mestre eminentíssimo que ao depois tive a fortuna de ver ao meu lado em cátedra em que ministramos o ensinamento da mesma disciplina jurídica, tinham sido o ditame de amizade que vem de longos anos. Em face porém do julgamento do Grande Juri, rendo-me, e de bom grado, à irrecorribilidade da decisão.

Sensibilizado e engrandecido, não ouso formular agradecimento que deslustraria a magnitude do prêmio e do julgado que mo adjudicou, tanto mais quanto, por seu significado, êle não me vem como estímulo, senão como dignidade augusta, que brasona de nobreza intelectual minha vida de jurista e de professor universitário.

\section{Mensagem do Presidente do Supremo Tribunal}

E' o seguinte o texto da mensagem enviada pelo eminente presidente do Supremo Tribunal Federal, ministro dr. Orosimbo Nonato da Silva, ao prof. Jorge Americano, presidente da Fundação Moinho Santista:

"Senhor presidente: Acuso, com prazer, o recebimento do ofício em que v. exa. se digna comunicar haver sido 
eleito o professor Waldemar Ferreira para receber o Prêmio Moinho Santista de 1958. Muito grato pela deferência, apraz-me cumprimentar o Juri por haver consagrado, com muita justiça, uma grande vida de cidadão e de mestre do direito e premiado uma brilhante e copiosa obra jurídica que honra a nossa cultura. Prevaleço-me do ensejo para externar a v. exa. os protestos de meu grande aprêço e distinta consideração. (as.) Ministro Orosimbo Nonato, presidente do Supremo Tribunal Federal".

\section{Mensagem do Presidente da República Italiana}

Achando-se em São Paulo no dia em que o Professor Waldemar Ferreira foi galardoado com o Prêmio Moinho Santista, o Exmo. Sr. Giovanni Gronchi, Presidente da República da Itália, dirigiu ao Professor Jorge Americano esta mensagem:

"A Itália e o Brasil se orgulham de suas tradições jurídicas e do intercâmbio que se estabeleceu, faz mais de um século, entre juristas italianos e brasileiros.

É motivo de satisfação verificar que, por ocasião da Visita Presidencial ao Brasil, o Prêmio Moinho Santista é concedido a um eminente jurista brasileiro, o Professor Dr. Waldemar Martins Ferreira, a quem o Brasil muito deve pela projeção que deu às suas letras jurídicas no exterior, elevando o nome da Universidade de São Paulo entre os centros universitários de todo o mundo latino.

Essse acontecimento tem importância não só pelo valor do Prêmio Moinho Santista, um milhão de cruzeiros, a maior recompensa científica da América, mas pela distinção acadêmica que representa.

(Ass.) Gronchi”

\section{Os têrmos do diploma}

São os seguintes os termos do artístico pergaminho entregue ao detentor do Prêmio Moinho Santista de 1958, 
datado de 30 de setembro de 1958, o qual traz a assinatura do ministro Orosimbo Nonato, presidente do Supremo Tribunal Federal e presidente do Grande Juri, do desembargador dr. João Marcelino Gonzaga, presidente do Tribunal de Justiça do Estado de São Paulo e vice-presidente do Grande Juri, do prof. Jorge Americano, presidente do Conselho Administrativo da Fundação Moinho Santista, e do dr. Eugenio Belotti, secretario da Fundação Moinho Santista :

“A Fundação Moinho Santista, de acôrdo com seus Estatutos e Regulamento, confere ao exmo. sr. prof. dr. Waldemar Martins Ferreira o Prêmio Moinho Santista de 1958, por ter realizado, com maior mérito, obra de excepcional projeção nacional e internacional e de inquestionável valor para o progresso das Ciências Especulativas, obtendo a consideração e o reconhecimento públicos por seus relevantes serviços prestados ás Ciências Jurídicas".

Homenagem da Faculdade de Direito da Universidade Mackenzie

Em sessão solene realizada aos 30 de outubro de $\mathbf{1 9 5 8 ,}$ na sala Couto de Magalhães, a Congregação da Faculdade de Direito da Universidade Mackenzie prestou homenagem ao Dr. Waldemar Ferreira, professor emérito da Faculdade de Direito da Universidade de São Paulo, por ter sido distinguido com o Prêmio Moinho Santista de 1958.

Presidiu a sessão o reitor da Universidade Mackenzie, professor Flamínio Fávero, presentes os professôres Jorge Americano, diretor da Faculdade de Direito, Alfredo Cecílio Lopes, Camilo Ashcar, Philomeno J. da Costa, José Barbosa de Almeida, Xavier de Brito, Hilário Veiga de Carvalho, Manuel Augusto Vieira Neto, Joaquim Canuto Mendes de Almeida, José Scaciotta e George Coelho Mendes de Souza. Tomou assento à mesa o Dr. José Ayres Netto.

Coube ao professor Philomeno J. da Costa saudar o professor Waldemar Ferreira, em nome da Congregação. 
Inicialmente, discorreu o orador sôbre o significado do Prêmio Moinho Santista e sôbre o critério que preside à outorga do galardão aos escolhidos. Referindo-se depois ao professor Waldemar Ferreira, chamou-o de "príncipe dos nossos comercialistas vivos, advogado pugnaz e jurispublicista do melhor tomo".

"Se por um processo de eleição das mais altas características - aduziu - se brinda um jurista, se galardoa um mestre, se recompensa um caráter, se laureia um sábio - esta Escola de Direito tinha também que acrescentar o tributo dos seus mais irrestritos aplausos. Engrandece-se quem espontânea e cordialmente reverencia os grandes".

Finalmente, apreciou o orador a obra jurídica de Waldemar Ferreira, fazendo especial menção à sua História do Direito Brasileiro, em quatro volumes, e aos seus trabalhos na Revista de Direito Mercantil, há oito anos em curso de publicação.

Em resposta, o professor Waldemar Ferreira proferiu o seguinte discurso:

"A glória do homem de bem, na prédica da Imitação de Cristo, é testemunha de boa consciência. Glória boni hominis testimonium bonae conscientiae. Habe bone conscientiam, nela se advertiu, \& habebis semper letitiam. Tende boa consciência e sempre possuireis alegria.

Conceituou-se a alegria dessarte como sendo o estado de conformidade de pensamentos e atos com os ditames de boa e sã consciência.

Poderia murmurar de mim para mim, se nesta assentada pùblicamente não o externasse, ter vivido nesse estado de graça advindo da consonância de meus atos e pensamentos com as diretrizes de consciência tranqüila de operário afeito a trabalho contínuo, nunca prolongado em excessos que levassem à fadiga, nem interrompido por ócios infindos, que o estagnassem no não fazer nada espiritual, gerador do tédio, fonte de tristeza.

Tanto que me iniciei no curso jurídico, vi-me na contingência, para levá-lo a bom pôrto, de fazer-me copista 
em oficina de notário, ofício modesto mantido durante um quinqüênio e só abandonado no momento da investidura do grau, que me ensejaria a tomada de posição profissional, para que me preparara na freqüência assídua ao ensinamento das cátedras.

Nisso assaz me empenhei; e me regosijo com o propósito. Era difícil o aprendizado jurídico, pela ausência, quase completa, de compêndios nacionais pelos quais se estudassem as disciplinas seriadas no currículo acadêmico.

Determinara a lei de 11 de agôsto de 1827, instituidora dos Cursos Jurídicos de São Paulo e de Olinda, que os seus lentes adotassem ou, inexistindo, escrevessem compêndios para o ensino de suas disciplinas, contanto que as doutrinas não fôssem desconformes com o sistema jurado da Nação.

Os compêndios, assim escritos, aprovados pelas Congregações dos Lentes, serviriam até que fôssem aceitos pela Assembléia Geral. Se o fôssem, o Govêrno Imperial os faria imprimir e fornecer aos Cursos Jurídicos, competindo a seus autores o privilégio exclusivo das obras por dez anos.

No cumprimento dêsse dispositivo, o primeiro lente do Curso Jurídico de São Paulo submeteu, sem êxito, à aprovação da Assembléia Geral, para servir de compêndio, os seus Princípios de Direito Natural. Fulminou-o parecer da Comissão de Instrução Pública da Câmara dos Deputados, ministrado em 1830, concluindo que aquêle compêndio não fôsse "admitido no Curso Jurídico, devendo-se ensinar o Direito Natural por outro compêndio, que melhor desempenhe a matéria".

Contribuiu êsse insucesso para que os demais lentes se esquivassem da elaboração de seus compêndios, desde então circulantes clandestinamente, sem aprovação das Congregações, sob a forma de postilas imperfeitamente taquigrafadas e publicadas "sem responsabilidade da ilustrada cadeira". 
Romperam com essa timidez os lentes de Direito Administrativo e de Processo, mantendo os demais o ineditismo que levou Teixeira de Freitas a havê-los "por Papinianos, mas de ciência guardada, só atestada por discípulos que adoram seu mestre e juram em sua palavra".

Manuseavam-se, no comêço do século, para o estudo do Direito, compêndios e tratados universitários estrangeiros, principalmente franceses e italianos, salvo, bem é de ver, quanto ao Processo e ao Direito Civil, que ainda era o das Ordenações do Reino. Constituiam raridades bibliográficas o Curso de Direito Civil Brasileiro do Conselheiro Antonio Joaquim Ribas e os Direitos da Família e o Direito das Cousas do Conselheiro Lafayette Rodrigues Pereira, as obras primas do direito privado brasileiro.

Sem declinar dos prazeres de que era pródiga a vida acadêmica de então, que vivi sem desperdício, intensa e mesmo vibrantemente, pois nos cantava aos ouvidos a ressonância do brado de Raul Pompéia de que vibrar era viver, pareceu-me indispensável a presença às aulas com disposição de acompanhá-las atentamente, tomando notas logo depois traduzidas e ampliadas em confronto com os textos e doutrinas referidos, em volumes manuscritos, alguns dos quais andaram de mão em mão até se perderem e outros ainda estantes, como relíquias preciosas, em minha biblioteca.

Com isso, mais o aprendido no meu ofício notarial de todos os dias, concluído o bacharelado jurídico, eu me fiz advogado provinciano em minha comarca de origem, fiel ao meu fadário profissional.

Adota-se uma profissão, como então escrevia Emile Faguet, tão em voga no mundo das letras internacionais, por um de dois motivos assaz diferentes: por vocação ou por falta de vocação, todos os dois análogos ao casamento. $\mathrm{O}$ primeiro é análogo ao casamento por amor. É o segundo análogo ao casamento de razão où de conveniência. A vocação, dizia o escritor francês, é amor vivo por ofício ou mister que se conhece pouco e com que se sonha muito. 
Como o casamento, advertia, apaixonadamente desejado, complacentemente desejado ou simplesmente aceito, a profissão requer adaptação, ajustamento. Tem-se nela maneira inventada para satisfação de necessidades gerais em que se depara qualquer coisa de universal, que cada individuo deve adotar e lhe imprime sua marca inconfundível. O advogado é o homem da lei, defensor e aplicador dela, mas que a lej envolve e absorve ou, para usar da expressão do escritor, "l'homme dont la loi a fait sa chose".

Atraía-me o pretório, desde a infâncía; e me pareceu a advocatura a condizente com os meus pendores, já então manifestos, para o cultivo das letras: era a vocação que se prenunciava.

Advogado sou há cinqüenta anos.

Do pretório não me afastou a política, que nele tem encontrado o seu mais rico manancial de servidores, pois que nele se enfileiram os homens da lei, senão quando, por circunstâncias históricas assaz conhecidas e nunca em demasia relembradas, me desterrou dêstes rincões prediletos para terras longínquas de além mar.

Também das lides forenses não me separou a cátedra universitária, que depois vim a obter, e me alargou os horizontes da ciência jurídica.

São os advogados, em regra, juristas de casos ocorrentes. A prática judiciária é absorvente e complexa; e os afazeres que ela impõe e exige de quantos nela se exercitam, não ensejam a serenidade indispensável para os estudos desinteressados e sistemáticos da ciência jurídica.

Caminhou-se, por isso mesmo, para o sistema da especialização profissional, sobretudo por se ter abandonado o sentido liberal da advocacia, convolada em emprêgo permanente e até entrosado no regime da Consolidação das Leis do Trabalho. Possui cada empresa o que se tem chamado de o "seu contencioso", para a solução de seus problemas jurídicos, com compartimentos mais especiali- 
zados ainda, em que avultam os setores trabalhistas e os fiscais. Implantou-se a especialização igualmente nos bancos, nas companhias de transportes, nas emprêsas de seguros ou de navegação marítima e aérea. Verificou-se o mesmo no fôro, em que constituem compartimentos estanques os dos criminalistas e os dos falencistas, cada qual com o seu sistema planetário adequadamente preparado Também no Ministério Público. Até nos Tribunais.

Esse especialismo profissional, que empolgou a advocatura, não é isolado. Mostrou-se entre nós até retar. datário. Chegou e converteu-se em realidade, à margem e a despeito do profissionalismo liberal que a transfundira de munus público em sacerdócio. Exprime-se, em verdade, por locação de serviço ou, melhor, por contrato de trabalho. Não que com isso se haja degradado. Nada disso! Modificou-se. Mudou de aspecto, por fôrça das contingências da vida contemporânea.

Pôs Ortega y Gasset sob o ângulo visual da objetiva de sua máquina de fotografia espiritual ao homem especializado, "exemplar dêste estranho homem novo" que intentou definir por uma e outra de suas vertentes e fases. Disse que era configuração humana sem par em tôda a história. Serve o especialista para concretizar enèrgicamente a espécie e divisar todo o radicalismo de sua novidade. Podiam os homens dividir-se antes em sábios e ignorantes, em mais ou menos sábios e mais ou menos ignorantes. Mas o especialista não se pode situar em nenhuma dessas categorias. Não é um sábio, porque ignora formalmente quanto não entre em sua especialidade; mas também não é um ignorante, porque é "um homem de ciência" e conhece muito bem a sua partícula do Universo. Melhor seria havê-lo como "um sábio-ignorante, coisa sobremaneira grave, pois significa que é um senhor que se comportará, em tôdas as questões que ignora, não como um ignorante, senão com a petulância de quem, em sua questão especial, é um sábio". 
É que, concluiu o pensador espanhol, "se o especialista desconhece a fisiologia interna da ciência que cultiva, muito mais radicalmente ignora as condições históricas de sua sobrevivência, isto é, como têm que estar organizados a sociedade e o coração do homem para que possam seguir seus destinos. $O$ descenso de vocações científicas, que nestes anos se observa, é sintoma preocupante para todo aquêle que tenha idéia clara do que é civilização, a idéia que sói faltar ao típico "homem de ciência", cimo de nossa atual civilização".

Poderei dizer de mim mesmo que me especializei, encerrando-me no âmbito do comercialismo?

Transferindo-me do fôro provinciano para o desta comarca, não tardou que as condiçốes desta imensa praça mercantil me conduzissem a prestar assistência profissional ao seu comércio atacadista, assoberbado por falências que se desfaziam em ruina total e em concordatas que se homologavam em propostas vis. Organizando-se em associação de classe, ao mesmo tempo em que entrou a agir no fôro em defesa dos credores seus componentes, lançou uma revista para maior eficiência daquele propósito, em que se estudassem os problemas jurídico-mercantis do momento. Os trabalhos forenses, que então elaborei, e os doutrinários, que nela escrevi, tiveram que se imprimir em volumes, um dos quais se ampliou em três edições sucessivas.

Com tudo isso, eu me achei, naquela oportunidade, que o destino me proporcionou, em ponto de atender a outro rumo de minha vocação, disputando a cátedra, que afinal alcancei, e ocupei durante trinta anos, de direito comercial na Faculdade de Direito de São Paulo.

Professor universitário, não vi nesse pôsto, apenas um título ou simples dignidade, nem tão pouco simples cargo público, senão, e em verdade, uma cátedra universitária, cheia de encargos, de deveres e de obrigações. Desde o primeiro momento, compreendi que deveria dar tudo quanto meu esfôrço permitisse, de molde a poder exigir alguma coisa de quantos me frequentassem as aulas. De 
ano para ano meu programa de ensino se modificou, depurou e ampliou, a fim de que não se anquilosasse nas postilas clandestinas, para o que elaborei cursos, instituições e tratados, em edições contínuas e sucessivas, revistos, aumentados e atualizados até o dia da impressão da última página.

Foi êsse labôr, que cessará sòmente quando meus olhos definitivamente se cerrarem para a leitura e meu espírito se transmigrar para o outro lado da vida, que justificou o voto do Grande Júri da Fundação Moinho Santista, concedendo-me o seu Prêmio de 1958. Adjudicou-mo, dizendo-me haver eu realizado obra de projeção e de valor para o progresso das ciências especulativas no àmbito das ciências jurídicas.

Que êsse nobre gesto me encheu de júbilo, eu não tenho ânimo para ocultar. Confesso-o, sem penitenciar-me, principalmente diante de vós, meus eminentes colegas e amigos reunidos nesta sessão solene da Congregação dos Professôres da Faculdade de Direito da Universidade Mackenzie, a que preside, por coincidência, o jurista insigne, Jorge Americano, que é presidente da Fundação Moinho Santista, e foi reitor magnífico da Universidade de São Paulo, de cuja Faculdade de Direito é catedrático, na qual todos os que aqui nos encontramos congregados recebemos o ensinamento e grau do bacharelado em ciências jurídicas e sociais.

Manifestando-me vosso júbilo, como o fizestes, com requintada galanteria, pela palavra do Professor Philomeno J. da Costa, ao qual me ligam antigos laços de companheirismo e amizade, vós, senhores professôres desta jovem Faculdade de Direito, bem exprimistes o alto grau de vosso espírito universitário". 